Revista de Administração Contemporânea

Journal of Contemporary Administration

http://rac.anpad.org.br

Maringá, PR, Brasil, v. 23, n. 6, art. 2, pp. 703-720, novembro/dezembro, 2019

Special Issue Corporate Governance Family Business

http://doi.org/10.1590/1982-7849rac2019190083

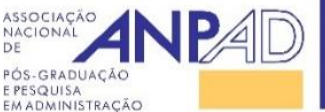

\title{
Conflicts in Boards of Family Firms: A Theoretical Framework for Strategic Decision-Making
}

\section{Conflitos em Conselhos de Empresas Familiares: Um Framework Teórico para o Processo Decisório Estratégico} \\ Pedro Braga Sotomaior Karam ${ }^{1}$ \\ Claudio Antonio Pinheiro Machado Filho ${ }^{1}$ \\ (iD) Gustavo Abib ${ }^{2}$
}

Universidade de São Paulo, Faculdade de Economia, Administração e Contabilidade, São Paulo, SP, Brasil ${ }^{1}$ Universidade Federal do Paraná, Departamento de Administração Geral e Aplicada, Curitiba, PR, Brasil ${ }^{2}$

Guest editors for this article: Aureliano Angel Bressan (D) Eduardo Schiehll iD Jairo Laser Procianoy

Luiz Ricardo Kabbach de Castro
Received 16 February 2019

Last version received at 27 August 2019

Accepted 30 August 2019

Editor-in-chief: Wesley Mendes-Da-Silva (ib)

\# of invited reviewers until the decision

\begin{tabular}{|c|c|c|c|c|c|c|c|c|}
\hline & 1 & 2 & 3 & 4 & 5 & 6 & 7 & 8 \\
\hline 1st round & & $\otimes$ & $\otimes$ & $\otimes$ & $\stackrel{\varphi}{5}$ & $\otimes$ & $\otimes$ & \\
\hline
\end{tabular}




\title{
Resumo
}

Conflitos são fenômenos sociais passíveis de ocorrem em qualquer tipo organizacional; entretanto, apresentam-se mais contundentes (e menos compreendidos) na dinâmica da empresa familiar, em função de efeitos psicodinâmicos exclusivos da interação entre família, gestão e propriedade. Paralelamente, conflitos podem ser também particularmente salientes no contexto ambíguo e complexo dos conselhos (a caixa-preta da governança corporativa), pela conexão íntima com decisões estratégicas. Interseccionando as áreas, este estudo propõe framework teórico conectando antecedentes e consequências de conflitos intragrupais no processo decisório estratégico (especialmente, na qualidade da decisão), no contexto particular e propício de conselhos de administração de empresas familiares. Baseado em lógica dedutiva, relacionamentos são construídos tendo em vista a função de aconselhamento estratégico de conselheiros, potencialmente elevando a qualidade de decisões estratégicas mediante redução da dimensão relacional e estímulo à discordância orientada à tarefa organizacional. Para tal, são propostas variáveis e constructos adequadas ao contexto sob investigação, em relações diretas e de moderação em lógica contingencial.

Palavras-chave: processo decisório estratégico, empresas familiares, conselhos de administração.

\begin{abstract}
Conflicts are social phenomena liable to occur in any organizational type; however, they're more intense (and less understood) in the family business dynamics, due to the unique psychodynamic effects of the interaction between family, management, and property. At the same time, conflicts can also be particularly salient in the ambiguous and complex context of boards (the black box of corporate governance), by the intimate connection with strategic decisions. Intersecting both areas, this study proposes a theoretical framework connecting antecedents and consequences of intragroup conflicts in the strategic decisionmaking process (especially in the decision quality), in the particular and favorable context of family firms board of directors. Based on deductive logic, relationships are built in view of the director' strategic counseling function, potentially raising the quality of strategic decisions by reducing the relational dimension and stimulating the organizational task-oriented discordance. Variables and constructs, suited to the specificities of the context under investigation, are proposed in direct and moderation relations under a contingency perspective.
\end{abstract}

Keywords: strategic decision-making, family business, boards of directors.

JEL Code: G3, D81, L21. 


\section{Introduction}

One of the main arguments employed to justify research focus on family business (FB) is the relevance of this organizational type to the global economy. Family enterprises are the prevailing corporate model in the world, with significant impact on the economy of emerging and developed nations (Sharma, Chrisman, \& Gersick, 2012). Brazil is no exception: it's estimated that approximately $80 \%$ of Brazilian companies are family owned (Instituto Brasileiro de Governança Corporativa [IBGC], 2018) - representing around 50\% of the gross domestic product. Consistent with practical relevance, FB research has been gaining momentum in recent years, reflected in the increase of publications, events and journals dedicated to the theme.

Although valid, the argument may not be sufficient to justify the recent research focus: the economic impact alone does not reflect the essence of family firms, whose specificity must rest on internal aspects, not on external consequences. In this sense, there's a consensus among scholars that it's the joint interaction of family relationships in the property and management subsystems what really makes FBs unique and particular (Astrachan, Klein, \& Smyrnios, 2002; Tagiuri \& Davis, 1996). As in no other organization, the dynamics of the family are present and active, shaping FB’s identity and strategic behavior (Astrachan, 2010).

Conflicts are good examples of phenomena that, although emerge as a theoretical and practical problem in all organizations (De Dreu \& Gelfand, 2008), are even more salient (and less understood) in the FB context (Kellermanns \& Eddleston, 2007; P. S. Davis \& Harveston, 2001). Exclusive psychodynamic effects of the interaction between family and organization (e.g. possible rivalries between relatives, marital problems, or the 2nd generation's desire to differentiate themselves from the founders) make family businesses specially suitable for applying and developing conflict theory (Kellermanns \& Eddleston, 2004; Memili, Chang, Kellermanns, \& Welsh, 2015). And with potentially critical consequences: conflicts are associated with reduced satisfaction (Nosé, Korunka, Frank, \& Danes , 2017), probability of low commitment of family members (Kidwell, Kellermanns, \& Eddleston, 2012), and the degree of subjectivity in which owners evaluate the value of their FB (Rousseau, Kellermanns, Zellweger, \& Beck, 2018).

However, contrary to common sense, functional effects could emerge from conflicts: researchers suggest that, when oriented to problem-solving, disagreements could stimulate the generation of alternatives, strengthen decision-making criteria, and create a commitment atmosphere among team members (Amason, 1996; De Wit, Greer, \& Jehn, 2012). In the literature this dimension is best known as task conflict (Jehn, 1994), understood as disagreements related to the content of a given task. While personally oriented divergences (relationship conflict) would consistently undermine organizational performance (McKee, Madden, Kellermanns, \& Eddleston, 2014), cognitive conflicts could, under certain conditions, show functional effects.

Revealing organizational circumstances under which conflicts that naturally emerge from social relations could benefit performance has therefore been the main goal of intragroup conflict literature (McKee et al., 2014). Notwithstanding, empirical researches have shown contradictory and/or inconclusive results, both in relation to firms in general (De Dreu \& Weingart, 2003; De Wit et al., 2012) and to family businesses (Frank, Kessler, Nosé, \& Suchy, 2011). Two theoretical gaps help explain inconsistency: (a) with rare exceptions (Eddleston \& Kellermanns, 2007), studies do not connect antecedents to the effects of conflicts, exploring the phenomenon without an integrative framework; and (b) in general, those focused on the consequences employ generic metrics as dependent variables (DV) - e.g. organizational performance or satisfaction -, considerably more distant from the social context where conflicts actually develop.

To present a theoretical framework capable of highlighting positive aspects of conflicts, in the specific context of the family firms' boards of directors, is the objective of this article. In addition to the unique psychodynamics of family businesses (Eddleston \& Kellermanns, 2007), the context is particularly conducive to the proposed investigation for at least three reasons: (a) boards of directors are strategic social arenas that, surprisingly, have been ignored in the literature on intragroup conflicts, which privileges the management domain (Eddleston, Otondo, \& Kellermanns, 2008; Ensley, Pearson, \& Sardeshmukh, 2007; Nosé et al., 2017) ; (b) boards have distinct characteristics and dynamics, such as the episodic nature, size and presence of independent directors 
(Leblanc \& Schwartz, 2007); and (c) whose strategic decision-making process (SDM), particularly appropriate to the strategic advisory function of directors (Bammens, Voordeckers, \& Van Gils, 2011), is intimately connected to conflicts (McKee et al., 2014).

Propositions are developed through deductive effort, employing arguments from stewardship and corporate governance theories applied to the family business context. The proposed framework differs by (a) an integrative approach, connecting antecedents and consequences of task and relationship conflicts in direct and moderation relation; (b) use of specific FB's and board's variables (e.g., emotional cohesion [family] and percentage of independent directors); and (c) investigated under the quality of strategic decisions - DV intrinsic to SDM (Nutt, 1998). Thus, this research seeks to pave the way for identifying potential benefits of intragroup conflict, whose practical effects are particularly relevant to family firms' boards of directors.

In addition to the introduction, this study is composed of three more sections: literature review, theoretical framework and conclusion.

\section{Literature Review}

Intragroup conflict is a social phenomenon present in the life of any human grouping (De Dreu \& Gelfand, 2008) and, although there is no single definition, can be understood as "the process emerging from perceived incompatibilities or differences among group members" (De Wit et al., 2012, p. 360). Incompatibility and difference are nouns usually associated with feelings of discomfort - emotions that, as a rule, human beings seek to avoid. At first latent, such emotions may manifest in reactions of aggression, irritation or distress (De Dreu \& Gelfand, 2008), generating unfavorable effects - such as dissatisfaction in the work environment, staff resentments, and declining productivity (De Dreu \& Weingart, 2003). It's not surprising, therefore, that traditional approaches to intragroup conflict takes a pessimistic perspective - in which managing conflicts means, basically, minimizing them (De Wit et al., 2012; Tjosvold, 1985).

Initially a minority voice in the literature, since the 1960 s there was the recognition that, at moderate levels, beneficial effects could emerge from conflicts (Deutsch, 1969). If it didn't extrapolated to personal questions, the confrontation of opinions and ideas could break the inertia of decision-making processes addicted to prefabricated solutions; also, ambiences open to debate - in which each member feels comfortable at expressing opinions (although disagreeing with others) -, would promote a more comprehensive understanding of the problem at hand, and may even result in interpersonal attraction and incorporation of opposing views. (Tjosvold, 1985). This perspective was systematized by Jehn (1994) when conceptualizing and operationalizing conflict not as a single but multiple construct, involving different dimensions and effects.

While personal disagreements - known as emotional (Jehn, 1994), affective (Amason, 1996) or relationship conflicts (De Dreu \& Weingart, 2003) - are associated with the harmful effects traditionally listed in the literature, task/substantive/cognitive conflicts involve divergences among team members about the content of organizational tasks. They emerge from differences in judgments or values, but related to work (Jehn, 1994; Mooney, Holahan, $\&$ Amason, 2007). Therefore, it's expected that, when related to non-routine activities and in moderate doses, this dimension will raise the quality of the SDM (De Wit et al., 2012; Jehn \& Mannix, 2001).

Two points deserve further elaboration. The first refers to the social context: it's believed that strategic arenas are the appropriate organizational level to reveal potential benefits of task conflicts. Due to requirements of strategic positions, it's plausible to assume that senior members have better skills and abilities to deal with complex interpersonal situations (De Wit et al., 2012). Additionally, it's suggested that the relationship between conflicts and performance is impacted by the nature of organizational work. According to Jehn and Mannix (2001), disagreements over routine tasks may not produce desirable effects; on the other hand in complex activities, involving considerable volume of information and search for customized solutions, the engagement of members in discussions is more likely to stimulate learning and innovation. 
Secondly it's believed that, in large intensity, even task conflicts could be dysfunctional - suggesting an inverted U-shape relationship with performance (Kellermanns \& Eddleston, 2004). One possible explanation refers to the interdependence between task and relationship conflicts: even when originally oriented to task resolution, disagreements could reach relational arenas, being interpreted as personal disagreements (Deutsch, 1969) and leading to "an escalation process that is difficult to deal with" (Frank et al., 2011, p. 131); i.e., there's a positive correlation between both dimensions (De Dreu \& Weingart, 2003; De Wit et al., 2012).

It's in the search for contexts and/or circumstances in which practitioners can obtain the benefits of disagreements without the associated costs that fall within the quantitative investigations of intragroup conflict. If the theoretical resolution seems relatively simple - balancing the task dimension simultaneously reducing the relational one - empirical results so far demonstrate that the question is far from being met. Contrary to the literature's optimism, De Dreu and Weingart (2003) indicate, through meta-analysis, a negative relation between task conflicts and performance. Also through meta-analysis, De Wit, Greer and Jehn (2012) suggest beneficial effects under three conditions: (a) when there's a low correlation between dimensions; (b) when conflict occurs at higher levels of organizational hierarchy; and (c) when performance is operationalized in financial or decisionmaking process terms. The resolution therefore assume contingential logic: conflicts can be productive under specific circumstances; discovering them has been the academic challenge.

\section{Intragroup conflicts in the FB context}

Discussions about conflicts in the organizational literature also fit into the context of family business; however, in an even more complex approach, due to the dynamics between family, management and ownership subsystems. In practice, there's some ambiguity in the distinction between family and management/director roles (Eddleston et al., 2008), so that conflicts originating within the family transcend organizational boundaries and vice versa. Another peculiarity is the greater psychological and social cost of excluding family members, who in general feel morally trapped in the organization, especially when they occupy high-ranking positions (Kellermanns \& Eddleston, 2004). It's in this sense that, according to Kellermanns and Eddleston, "effects and implications of conflict in family firms are more complex than in non-family managed business and therefore, the ways conflict can improve or impede a family business must be understood" (2004, p. 210).

Consistent with Nordqvist (2012), a family-owned business is an organization whose ownership is controlled (via a majority of the shares/quotas or shareholders' agreement) by one or more families, and the family is represented in strategic teams. Therefore, two are the criteria adopted in this research: (a) ownership (in the traditional sense); and (b) representation of the controlling family(ies) in the board of directors.

In literature review on intragroup conflict in FBs, three main themes are identified by Frank, Kessler, Nosé and Suchy (2011): (a) investigations into the causes of conflicts; (b) effects on performance; and (c) conflict management. For being theoretically closer to the scope of this research, also concentrating most of the empirical efforts (Nosé et al., 2017), emphasis is given to the first two branches. Based on the authors' research, but updated by searching on the Web of Science and Scopus databases with the terms conflict, family business* and decision making, 9 articles dealing specifically with the causes and/or consequences of conflicts have been identified over the last 20 years (1999-2018). A synthesis can be seen in Table 1; for purposes of space saving, only hypotheses related to the paradox are identified, identifying the appropriate locus (antecedent or consequence) as well as main contributions to the conflict theory in the family enterprise. 
Table 1

\section{Years of Research on Antecedents and Consequences of Intragroup Conflict on Family Businesses}

\begin{tabular}{|c|c|c|c|c|}
\hline Title (Author, Year) & Main Purpose & Sample & Hypotheses & Main Contributions \\
\hline \multirow{7}{*}{$\begin{array}{l}\text { In the founder's } \\
\text { shadow: Conflict in } \\
\text { the family firm (P. } \\
\text { S. Davis \& } \\
\text { Harveston, 1999) }\end{array}$} & \multirow{7}{*}{$\begin{array}{l}\text { Examine the effects } \\
\text { of the founder's } \\
\text { influence } \\
\text { (founder's shadow) } \\
\text { on conflicts in FBs. }\end{array}$} & \multirow{7}{*}{$\begin{array}{l}\text { CEO of } 1002 \\
\text { American FBs }\end{array}$} & H1: Conflict will be greater in FBs led by the & \multirow{7}{*}{$\begin{array}{l}\text { Non-rejected hypotheses: } \mathrm{H} 2 \mathrm{a} \text { and } \mathrm{H} 3 \mathrm{a} \text {. } \\
\text { Investigating antecedents of substantive (task) } \\
\text { conflicts, the authors confirm the general } \\
\text { tendency of increase as new family members } \\
\text { (2nd, 3rd generations) take over the FB. } \\
\text { However, more than the generation itself, it's the } \\
\text { founder's resistance to letting control (founder's } \\
\text { shadow) the main predictor of substantive } \\
\text { conflicts - especially in the transition from the } \\
\text { first to the second generation. }\end{array}$} \\
\hline & & & $\begin{array}{l}\text { 2nd generation than by the founder. } \\
\text { (Antecedent) }\end{array}$ & \\
\hline & & & $\mathrm{H} 2 \mathrm{a}$ : Conflict will be greater among FBs & \\
\hline & & & $\begin{array}{l}\text { managed by the } 3 \text { rd (or other) generation than } \\
\text { by the founder or } 2 \text { nd generation. } \\
\text { (Antecedent) }\end{array}$ & \\
\hline & & & $\begin{array}{l}\mathrm{H} 2 \mathrm{~b} \text { : The increase in conflict between FBs } \\
\text { from } 2 \text { nd to } 3 \mathrm{rd} \text { generation will be lower than } \\
\text { the increase from } 1 \text { st to } 2 \text { nd generation. } \\
\text { (Antecedent) }\end{array}$ & \\
\hline & & & $\begin{array}{l}\text { H3a: Conflict will be greater in the presence } \\
\text { of the founder's shadow. (Antecedent) }\end{array}$ & \\
\hline & & & $\begin{array}{l}\text { H3b: The presence or absence of subsequent } \\
\text { generations' influence will not affect } \\
\text { conflicts. (Antecedent) }\end{array}$ & \\
\hline \multirow{7}{*}{$\begin{array}{l}\text { The phenomenon of } \\
\text { substantive conflict } \\
\text { in the family firm: } \\
\text { A cross- } \\
\text { generational study } \\
\text { (P. S. Davis \& } \\
\text { Harveston, 2001) }\end{array}$} & \multirow{7}{*}{$\begin{array}{l}\text { To examine the } \\
\text { family influence on } \\
\text { conflicts, as well as } \\
\text { their diffusion } \\
\text { through } \\
\text { generations. }\end{array}$} & \multirow{7}{*}{$\begin{array}{l}\text { CEO of } 1002 \\
\text { American FBs }\end{array}$} & H1: The higher the number/level of & \multirow{5}{*}{$\begin{array}{l}\text { Non-rejected hypotheses: } \mathrm{H} 2 \text { and } \mathrm{H} 4 \text {. } \\
\text { Once more analyzing sources of substantive } \\
\text { conflicts, the authors indicate that the effect of } \\
\text { generation is not only direct (positive) but also } \\
\text { moderating over other (demographic) family } \\
\text { variables. The pacifying role of external relatives } \\
\text { - whose presence tends to reduce conflicts in the } \\
\text { third generation - is also highlighted. }\end{array}$} \\
\hline & & & $\begin{array}{l}\text { affiliation/hierarchical position of relatives, } \\
\text { the lesser the conflict in FBs. (Antecedent) }\end{array}$ & \\
\hline & & & $\begin{array}{l}\mathrm{H} 2 \text { : The higher the number of external } \\
\text { relatives (not involved in the day-to-day }\end{array}$ & \\
\hline & & & $\begin{array}{l}\text { work), the lesser the conflict in FBs. } \\
\text { (Antecedent) }\end{array}$ & \\
\hline & & & H3: The more social interactions among & \\
\hline & & & $\begin{array}{l}\text { family members, the lesser the conflict in } \\
\text { FBs. (Antecedent) }\end{array}$ & \multirow{2}{*}{$\begin{array}{l}\text { Unlike previous study (P. S. Davis \& Harveston, } \\
\text { 1999), the research draws attention to the roles of } \\
\text { other family members in the dynamics of conflict } \\
\text { in FBs. }\end{array}$} \\
\hline & & & $\begin{array}{l}\text { H4: The relationship between family } \\
\text { variables and conflict will be moderated by } \\
\text { the FB's generation. (Antecedent) }\end{array}$ & \\
\hline
\end{tabular}

Continues 
Table 1 (continued)

\begin{tabular}{|c|c|c|c|c|}
\hline Title (Author, Year) & Main Purpose & Sample & Hypotheses & Main Contributions \\
\hline $\begin{array}{l}\text { Destructive and } \\
\text { productive family } \\
\text { relationships: A } \\
\text { stewardship theory } \\
\text { perspective } \\
\text { (Eddleston \& } \\
\text { Kellermanns, 2007) }\end{array}$ & $\begin{array}{l}\text { To investigate the } \\
\text { influence of } \\
\text { relational conflict } \\
\text { and participative } \\
\text { strategy process on } \\
\text { FB's performance. }\end{array}$ & $\begin{array}{l}\text { Top Management } \\
\text { Team (TMT) of } 60 \\
\text { American FBs }\end{array}$ & $\begin{array}{l}\text { H1: Altruism is negatively related to } \\
\text { relationship conflict (Antecedent) } \\
\text { H4: Control concentration is positively } \\
\text { related to relationship conflict (Antecedent) } \\
\text { H6. Participative strategy process is } \\
\text { negatively related to relationship conflict } \\
\text { (Antecedent) } \\
\text { H7. Relationship conflict is negatively related } \\
\text { to performance (Consequence) }\end{array}$ & $\begin{array}{l}\text { Non-rejected hypotheses: } \mathrm{H} 1 \text { and } \mathrm{H} 7 \text {. } \\
\text { Employing stewardship theory, the study } \\
\text { innovates by focusing on relationship conflicts in } \\
\text { FBs. Convergent with theoretical expectation, a } \\
\text { negative impact on performance (subjectively } \\
\text { measured) is demonstrated. Altruism, on the } \\
\text { other hand, emerges as a reducer of personal } \\
\text { friction (negative relation with relationship } \\
\text { conflict) - suggesting steward relationships as } \\
\text { potential sources of competitive advantage for } \\
\text { FBs. }\end{array}$ \\
\hline $\begin{array}{l}\text { A family } \\
\text { perspective on } \\
\text { when conflict } \\
\text { benefits family firm } \\
\text { performance } \\
\text { (Kellermanns \& } \\
\text { Eddleston, 2007) }\end{array}$ & $\begin{array}{l}\text { To examine the } \\
\text { effects of cognitive } \\
\text { and processual } \\
\text { conflicts on FB's } \\
\text { performance. }\end{array}$ & $\begin{array}{l}\text { CEO and family } \\
\text { members of } 51 \\
\text { American FBs }\end{array}$ & $\begin{array}{l}\text { H1: Cognitive conflict is positively related to } \\
\text { FB performance. (Consequence) } \\
\text { H2: Process conflict is positively related to } \\
\text { FB performance. (Consequence) } \\
\text { H3a,b: The relationship between (a) cognitive } \\
\text { conflict and (b) process conflict and family } \\
\text { firm performance is moderated by family- } \\
\text { member exchange (enhancing the positive } \\
\text { relation). (Consequence) } \\
\text { H4a,b: H4: The relationship between (a) } \\
\text { cognitive conflict and (b) process conflict and } \\
\text { family firm performance is moderated by } \\
\text { generational ownership dispersion. } \\
\text { Specifically, higher levels of cognitive and } \\
\text { process conflict are beneficial in family firms } \\
\text { with low ownership dispersion, while lower } \\
\text { levels of cognitive and process conflict are } \\
\text { beneficial in family firms with higher levels } \\
\text { of generational ownership dispersion. } \\
\text { (Consequence) }\end{array}$ & $\begin{array}{l}\text { Non-rejected hypotheses: } \mathrm{H} 3 \mathrm{~b} \text { and } \mathrm{H} 4 \mathrm{a} \text {. } \\
\text { Contrary to expected, no positive relationships } \\
\text { between cognitive/processual conflicts and } \\
\text { performance (subjectively measured) were } \\
\text { found. } \\
\text { In the 1st generation however, high levels of } \\
\text { cognitive conflicts would benefit performance } \\
\text { (what doesn't occur when the property is } \\
\text { dispersed in several relatives) - suggesting an } \\
\text { important role of generation as moderator. } \\
\text { The article's main contribution is the empirical } \\
\text { evidence that, depending on the context, task } \\
\text { conflicts would favor family firms - in this case, } \\
\text { enhancing performance in the first generation. }\end{array}$ \\
\hline
\end{tabular}




\section{Table 1 (continued)}

\begin{tabular}{|c|c|c|c|c|}
\hline Title (Author, Year) & Main Purpose & Sample & Hypotheses & Main Contributions \\
\hline $\begin{array}{l}\text { The negative } \\
\text { consequences of } \\
\text { pay dispersion in } \\
\text { family and non- } \\
\text { family top } \\
\text { management teams: } \\
\text { An exploratory } \\
\text { analysis of new } \\
\text { venture, high- } \\
\text { growth firms } \\
\text { (Ensley et al., 2007) }\end{array}$ & $\begin{array}{l}\text { Explore the impact } \\
\text { of wage dispersion } \\
\text { on conflict, } \\
\text { cohesion, and } \\
\text { power on TMTs of } \\
\text { family and non- } \\
\text { family firms. }\end{array}$ & $\begin{array}{l}\text { TMT of } 200 \\
\text { venture firms }(112 \\
\text { FBs })\end{array}$ & $\begin{array}{l}\mathrm{H} 2 . \text { Wage dispersion in TMTs raises affective } \\
\text { (relationship) conflict. This relationship will } \\
\text { be stronger in FBs. (Antecedent) } \\
\text { H3. Wage dispersion in TMT reduces } \\
\text { cognitive (substantive) conflict. This } \\
\text { relationship will be stronger in FBs. } \\
\text { (Antecedent) }\end{array}$ & $\begin{array}{l}\text { Non-rejected hypotheses: } \mathrm{H} 2 \text { and } \mathrm{H} 3 \text {. } \\
\text { Unlike previous articles, the study innovates by } \\
\text { comparing family and non-family businesses. As } \\
\text { predicted, it's shown that wage dispersion raises } \\
\text { affective conflict and reduces the cognitive facet } \\
\text { especially in FBs - according to the authors, due } \\
\text { to the clash between economic logic } \\
\text { (meritocratic remuneration) and the altruistic } \\
\text { pattern of family social relations. }\end{array}$ \\
\hline $\begin{array}{l}\text { Conflict, } \\
\text { participative } \\
\text { decision-making, } \\
\text { and generational } \\
\text { ownership } \\
\text { dispersion: A } \\
\text { multilevel analysis } \\
\text { (Eddleston et al., } \\
\text { 2008) }\end{array}$ & $\begin{array}{l}\text { To evaluate how } \\
\text { the dispersion of } \\
\text { generational } \\
\text { property moderates } \\
\text { relations between } \\
\text { participative } \\
\text { decision-making } \\
\text { and cognitive/ } \\
\text { relationship } \\
\text { conflicts. }\end{array}$ & $\begin{array}{l}\text { CEO and other } \\
\text { family members of } \\
37 \text { American FBs }\end{array}$ & $\begin{array}{l}\text { H1: Participative decision-making is } \\
\text { positively related to cognitive conflict. } \\
\text { (Antecedent) } \\
\text { H2: Participative decision-making is } \\
\text { negatively related to relationship conflict. } \\
\text { H3a: Generational ownership dispersion (firm } \\
\text { level) will exhibit a direct cross-level } \\
\text { relationship with cognitive conflict } \\
\text { (individual level). (Antecedent) } \\
\text { H3b: The relationship between participative } \\
\text { decision-making and cognitive conflict will } \\
\text { be moderated by generational ownership } \\
\text { dispersion (firm level). (Antecedent) } \\
\text { H4a: Generational ownership dispersion (firm } \\
\text { level) will exhibit a direct cross-level } \\
\text { relationship with relationship conflict } \\
\text { (individual level). (Antecedent) } \\
\text { H4b: The relationship between participative } \\
\text { decision-making and relationship conflict } \\
\text { (individual level) will be moderated by } \\
\text { generational ownership dispersion (firm } \\
\text { level). (Antecedent) }\end{array}$ & $\begin{array}{l}\text { Non-rejected hypotheses: } \mathrm{H} 2, \mathrm{H} 3 \mathrm{~b} \text { and } \mathrm{H} 4 \mathrm{~b} \text {. } \\
\text { Adopting a contingency approach, it can be } \\
\text { observed that, in the } 1 \text { st or } 2 \text { nd generation, } \\
\text { greater participation in the decision-making } \\
\text { process reduces cognitive and relationship } \\
\text { conflicts in FBs. However, the effect reverses } \\
\text { with property is dispersed over several } \\
\text { generations - increasing both dimensions. } \\
\text { The article offers an interesting practical } \\
\text { contribution: the ideal level of participative } \\
\text { decision-making (managerial variable) is } \\
\text { contingent on the FB generation, due to the } \\
\text { different effects on the task and relational facets } \\
\text { of conflicts. }\end{array}$ \\
\hline
\end{tabular}


Table 1 (continued)

\begin{tabular}{|c|c|c|c|c|}
\hline Title (Author, Year) & Main Purpose & Sample & Hypotheses & Main Contributions \\
\hline \multirow{4}{*}{$\begin{array}{l}\text { Harmony, justice, } \\
\text { confusion, and } \\
\text { conflict in family } \\
\text { firms: Implications } \\
\text { for ethical climate } \\
\text { and the "Fredo } \\
\text { effect" (Kidwell et } \\
\text { al., 2012) }\end{array}$} & \multirow{4}{*}{$\begin{array}{l}\text { Investigate factors } \\
\text { influencing the } \\
\text { probability of } \\
\text { family member } \\
\text { impediment, which } \\
\text { can lead to } \\
\text { unethical behavior. }\end{array}$} & \multirow{4}{*}{$\begin{array}{l}\text { Family members of } \\
121 \text { American FBs }\end{array}$} & \multirow{3}{*}{$\begin{array}{l}\text { H4a: Relationship conflict mediated the } \\
\text { relationship between perceived norms of } \\
\text { family harmony and family impediment. } \\
\text { (Mediation) } \\
\text { H4b: Relationship conflict mediated the } \\
\text { relationship between perceptions of } \\
\text { distributive fairness and family impediment. } \\
\text { (Mediation) }\end{array}$} & \multirow{3}{*}{$\begin{array}{l}\text { Non-rejected hypotheses: } \mathrm{H} 4 \mathrm{a}, \mathrm{H} 4 \mathrm{~b} \text { and } \mathrm{H} 4 \mathrm{c} \text {. } \\
\text { Focus on relationship conflict and its ability to } \\
\text { destroy value - in this case, emerging as the } \\
\text { main influencer of low familial involvement in } \\
\text { FBs (known as the Fredo effect). In turn, } \\
\text { perceived norms of family harmony and } \\
\text { perceptions of distributive fairness would reduce } \\
\text { relationship conflicts. }\end{array}$} \\
\hline & & & & \\
\hline & & & & \\
\hline & & & $\begin{array}{l}\text { H4c: Relationship conflict mediated the } \\
\text { relationship between role ambiguity and } \\
\text { family impediment. (Mediation) }\end{array}$ & $\begin{array}{l}\text { Authors suggest that by minimizing relationship } \\
\text { conflicts, perceptions of an ethical, cooperative, } \\
\text { and transparent organizational climate would } \\
\text { also reduce the problem of low involvement of } \\
\text { family members in family firms (dependent } \\
\text { variable) - strengthening the stewardship } \\
\text { approach. }\end{array}$ \\
\hline \multirow{6}{*}{$\begin{array}{l}\text { Decreasing the } \\
\text { effects of } \\
\text { relationship conflict } \\
\text { on family } \\
\text { businesses: The } \\
\text { moderating role of } \\
\text { family climate } \\
\text { (Nosé et al., 2017) }\end{array}$} & \multirow{6}{*}{$\begin{array}{l}\text { To examine the } \\
\text { effect of positive } \\
\text { family climate on } \\
\text { the association } \\
\text { between } \\
\text { relationship conflict } \\
\text { and performance } \\
\text { metrics - } \\
\text { organizational } \\
\text { satisfaction and } \\
\text { performance. }\end{array}$} & \multirow{6}{*}{$\begin{array}{l}\text { Owners and top } \\
\text { managers of } 392 \\
\text { Australian FBs }\end{array}$} & \multirow{4}{*}{$\begin{array}{l}\text { H1: Relationship conflict is negatively related } \\
\text { to a) satisfaction and b) performance } \\
\text { (organizational level). (Consequence) } \\
\text { H3a (a,b,c): The relationship between } \\
\text { relationship conflict and satisfaction is } \\
\text { moderated by (a) cohesion, (b) adaptability } \\
\text { and (c) open communication, reducing its } \\
\text { negative effect. (Consequence) }\end{array}$} & $\begin{array}{l}\text { Non-rejected hypotheses: H1a, H1b, H3a (a), } \\
\text { H3a (b) and H3b (c). }\end{array}$ \\
\hline & & & & \multirow{2}{*}{$\begin{array}{l}\text { Again exploring relationship conflicts, results } \\
\text { indicate (according to literature) negative } \\
\text { relation with organizational } \\
\text { performance/satisfaction. }\end{array}$} \\
\hline & & & & \\
\hline & & & & \multirow{2}{*}{$\begin{array}{l}\text { The novelty is found in moderation relationships: } \\
\text { it's shown that the detrimental effect is lesser } \\
\text { when coupled with cohesion and family } \\
\text { adaptability. }\end{array}$} \\
\hline & & & \multirow{2}{*}{$\begin{array}{l}\mathrm{H} 3 \mathrm{~b}(\mathrm{a}, \mathrm{b}, \mathrm{c}) \text { : The relationship between } \\
\text { relationship conflict and performance is } \\
\text { moderated by (a) cohesion, (b) adaptability } \\
\text { and (c) open communication, reducing its } \\
\text { negative effect. (Consequence) }\end{array}$} & \\
\hline & & & & $\begin{array}{l}\text { Although there's no evidence of positive effects } \\
\text { of relationship conflicts, authors suggest that a } \\
\text { positive family climate (cohesion/adaptive } \\
\text { capacity) can minimize negative effects - } \\
\text { corroborating the stewardship approach as a } \\
\text { potential competitive advantage of FBs. }\end{array}$ \\
\hline
\end{tabular}




\section{Table 1 (continued)}

\begin{tabular}{|c|c|c|c|c|}
\hline Title (Author, Year) & Main Purpose & Sample & Hypotheses & Main Contributions \\
\hline $\begin{array}{l}\text { Relationship } \\
\text { conflict, family } \\
\text { name congruence, } \\
\text { and socioemotional } \\
\text { wealth in family } \\
\text { firms (Rousseau et } \\
\text { al., 2018) }\end{array}$ & $\begin{array}{l}\text { To investigate how } \\
\text { owners consider the } \\
\text { socio-emotional } \\
\text { cost of relationship } \\
\text { conflicts in } \\
\text { valuations of the } \\
\text { value of the family } \\
\text { firm. }\end{array}$ & $\begin{array}{l}149 \text { CEOs /owners } \\
\text { of German FBs }\end{array}$ & $\begin{array}{l}\text { H1: There's a non-linear relation between } \\
\text { relationship conflict and the degree of } \\
\text { subjectivity in the evaluation of the value of } \\
\text { FBs by the owners. Specifically, low and high } \\
\text { levels of relationship conflict correspond to } \\
\text { more subjective assessments; moderate, to } \\
\text { less subjective assessments. (Consequence) } \\
\text { H3: Relationship conflict and congruence of } \\
\text { name (family name = business name) interact, } \\
\text { reversing the H1 relation. When there's } \\
\text { congruence, an inverted U-relationship is } \\
\text { expected between relationship conflict and } \\
\text { subjectivity in assessing the value of FB. } \\
\text { (Consequence) }\end{array}$ & $\begin{array}{l}\text { Non-rejected hypotheses: } \mathrm{H} 1 \text { and } \mathrm{H} 3 \text {. } \\
\text { In this study, it's adopted an unprecedented DV: } \\
\text { the subjectivity in the monetary value that } \\
\text { owners assign to FBs. Results can't refuse } \\
\text { proposed hypotheses, demonstrating complex } \\
\text { nonlinear relations with relationship conflict } \\
\text { (understood as a social-emotional cost). } \\
\text { In particular, two points are highlighted: } \\
\text { (a) there seems to be a tendency in the literature } \\
\text { for investigating relationship conflict; } \\
\text { (b) whose organizational impacts } \\
\text { seem wider than previously foreseen in conflict } \\
\text { theory. }\end{array}$ \\
\hline
\end{tabular}

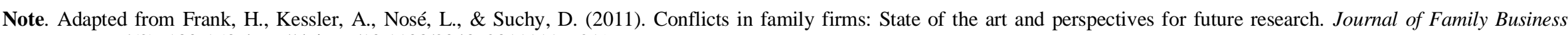
Management, 1(2), 130-153. http://doi.org/10.1108/20436231111167219 
Interesting analyzes can be drawn from Table 1. Firstly, the topic is still underexplored in the FB literature, which can be proven by the low number of papers over two decades. It's also verified the destructive capacity of relationship conflicts and the predominance of stewardship theory (J. H. Davis, Schoorman, \& Donaldson, 1997) as an approach to minimize both their incidence/intensity and organizational consequences - through constructs such as altruism (Eddleston \& Kellermanns, 2007), participative decision-making (Eddleston et al., 2008), and family cohesion (Nosé et al., 2017). Convergently, Ensley, Pearson and Sardeshmukh (2007) demonstrate that greater wage dispersion in TMT raises the probability of relationship conflicts. In this sense, the stewardship approach is pointed out as a potential source of family firm's competitive advantage by attenuating the incidence and dysfunctional effects of the relational dimension (Eddleston \& Kellermanns, 2007; Kidwell et al., 2012).

If there's convergence on the (dysfunctional) organizational effects of relationship conflicts, the same can't be said in relation to the task dimension. Contrary to theoretical expectations, empirical results in Kellermanns and Eddleston (2007) point out that, in general, even task-oriented disagreements would impair performance. However, the relationship is positive when property is concentrated in the first generation, becoming negative as FB's lifecycle is advanced - suggesting that potential beneficial effects of discordance would be mitigated and even inverted as new descendants take over the property.

Another observation concerns flexibility in theoretical applications: as Rousseau, Kellermanns, Zellweger, and Beck (2018) points out, conflicts may present broader ramifications than initially considered in the literature, especially in the FB context. In addition to the connection with organizational performance and/or satisfaction (Eddleston \& Kellermanns, 2007; Kellermanns \& Eddleston, 2007; Nosé et al., 2017), conflicts seem to be related to subjectivity in the monetary value attributed by owners to the organization (Rousseau et al., 2018), and to the probability of low commitment of relatives (Kidwell et al., 2012) - a research area rich in theoretical possibilities.

Two academic gaps deserve attention. Surprisingly due to the intrinsic connection with strategic decisions (Eddleston et al., 2008; Mooney et al., 2007), there's no research on the consequences of conflicts on SDM metrics. Even in the broader spectrum of the organizational literature, few studies explore the impacts of conflicts in decision-making (De Dreu \& Weingart, 2003; De Wit et al., 2012) - exceptions can be found in De Wit, Jehn and Scheepers (2013) and Olson, Parayitam and Bao (2007). Also, no research has been conducted in the particular context of FB boards of directors, possibly due to the difficulties of accessing and exploring board process - the black box of corporative governance (Leblanc \& Schwartz, 2007).

\section{Theoretical Framework}

Based on deductive logic the proposed framework includes antecedents, conflict dimensions and SDM effects in a contingency logic, contemplating direct and moderation relations - as seen in Figure 1. It's assumed that relations in the family subsystem influence strategic processes and dynamics (Astrachan, 2010).

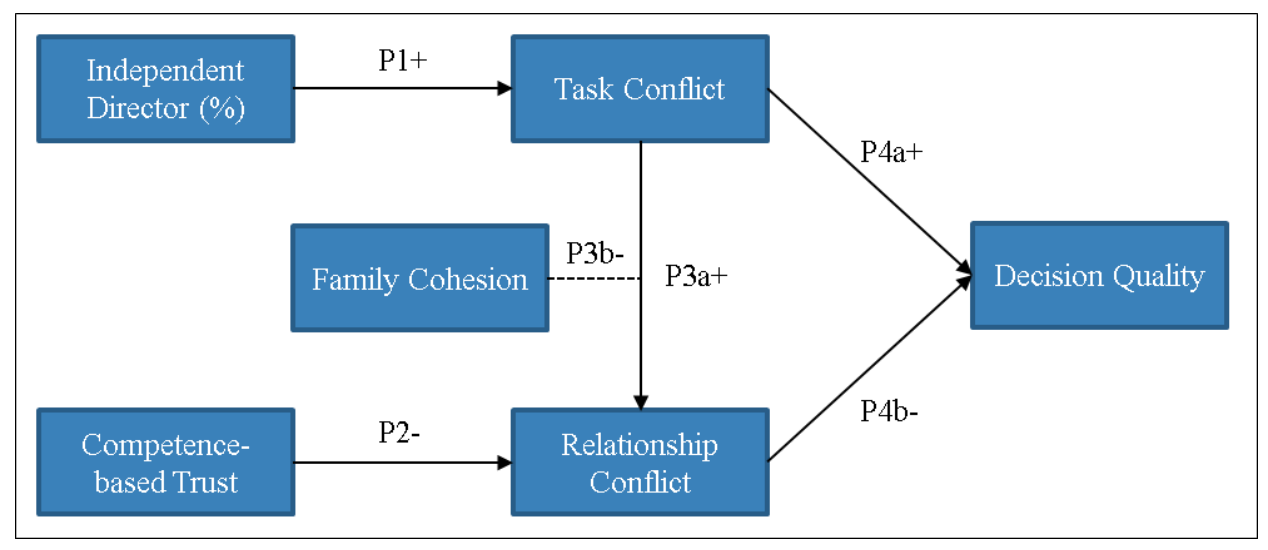

Figure 1. Theoretical Framework, Intragroup Conflicts in FB Boards 


\section{Antecedents of conflicts}

It's believed that the percentage of independent board members and the construct competence-based trust influence, respectively, the emergence/intensity of taks and relationship conflicts.

\section{Independent board members (\%)}

Although with small variations in the literature, there's consensus that the independent member is one who doesn't have relations, of any nature, with the organization (Monks \& Minow, 2004) - beyond be a board member. Employees would naturally be excluded; apart from these, service providers (e.g., consultants, lawyers), suppliers, and/or customers would not fit the definition either. In the context of the family business, however, another important filter should be added: even if they don't have employment or commercial ties, family members could not be independent due to the obvious kinship relationships.

In the Brazilian context, the presence of independent board members is a legal requirement for publicly traded companies listed in special segments - e.g., minimum of two independent directors or $20 \%$ of the board composition (whichever is greater) in B3's special Nível 2 and Novo Mercado listing segments (B3, n.d.). According to the Brazilian Institute of Corporative Governance (IBGC, as it's known in Portuguese), this is also one of the best corporate governance practices recommended for promoting "independence in the judgment of all directors and the integrity of the governance system" (2015, p. 45). It lies in the unbiased discordance, based on judgments oriented to the resolution of organizational tasks - i.e., on the beneficial potential of task conflicts (Jehn, 1994) - the main contribution of the independent board member.

As a demographic variable related to diversity in councils, the proportion of independents tends to promote cognitive conflict (Forbes \& Milliken, 1999), by the absence of links and (at least theoretically) conflicts of interest. Because they share few experiences with management and greater freedom/autonomy of thought, the effort of independents would be more directed, according to Forbes and Milliken (1999) and Monks and Minow (2004), to the achievement of organizational objectives - including questions with executive and board members. The non-family bond also emerges as a stimulus: the external view can bring what Eisenhardt (1989) denominates aeration of ideas, because independents are not conditioned by the sets of beliefs and judgments shared by the family. Therefore it's stated that:

P1: the greater the proportion of independent members in family firm boards, the greater the intensity of task conflicts.

\section{Competence-based trust}

Employed in several academic areas, trust is one of the key constructs of stewardship theory (Eddleston \& Kellermanns, 2007; J. H. Davis et al., 1997) and also important in the family business literature (Corbetta \& Salvato, 2004; Eddleston \& Morgan, 2014). In this study it's investigated a specific type of trust, emerging from cognitive processes - specifically when the trustor, choosing whom to trust (albeit unconsciously), is based on the respect and competence attributed to the trusted (Olson, Parayitam, \& Bao, 2007). Thus, team members who share a high level of competence-based trust (cbt) would develop mutual respect based on the belief that peers are capable of solving organizational problems. The respect and trust derived from the competence would stimulate, for Olson et al. (2007), the sharing of information and perspectives among members, raising the likelihood of task conflicts - relationship not rejected in the context of American health industry's TMTs.

Based on the argument that interpersonal trust is an important feature of cooperative and pro-organizational teams (J. H. Davis et al., 1997) and on empirical evidence relating negatively stewardship constructs and relationship conflict in family businesses (Eddleston \& Kellermanns, 2007; Eddleston et al., 2008; Nosé et al., 2017), it's understood that cbt can negatively influence interpersonal disagreements. In boards where trust through competence (an important prerequisite) is predominant among members, strategic discussions are more likely to 
be guided by professionalism and mutual respect, thus minimizing the intensity of relationship conflicts. Therefore:

P2: Competence-based trust is negatively related to the intensity of relationship conflicts in FB boards.

\section{Relationships between intragroup conflicts in FB}

As previously argued, meta-analyzes indicate that task and relational facets have a positive and significant correlation (De Dreu \& Weingart, 2003; De Wit et al., 2012), showing the tendency to conflict escalation (Deutsch, 1969) and the notion that, at high levels, work-oriented disagreements could be interpreted as personal disputes, converting into relationship conflicts that undermine group dynamics (Kellermanns \& Eddleston, 2004). Notwithstanding, it's believed that emotional cohesion among family members - a specific FB variable moderates the relationship, mitigating its strength.

\section{Emotional cohesion (family level)}

In the systems theory perspective, families are open systems whose dependence on the environment regulates internal and external interactions for the maintenance of an equilibrium state (Björnberg \& Nicholson, 2007). Its boundaries derive from the degree of cohesion between family members, defined by Björnberg and Nicholson (2007) as the emotional and cognitive glue that unites them as a family - important for the survival of the system especially in times of crisis. Cohesion would be one of the pillars of the positive family climate, capturing the quality of interpersonal relationships in two dimensions: cognitive, reflecting sharing and understanding of norms/values, and emotional, contemplating the strength of family ties through aspects such as security and affection that members nourish with each other (Björnberg \& Nicholson, 2007).

Emotional cohesion is also a trait of stewardship behavior (Björnberg \& Nicholson, 2007). According to Corbetta and Salvato (2004), the extent to which family ties are imbued with emotions and feelings favors the development of a collectivist culture in $\mathrm{FB}$, in which organizational goals prevail over personal ones. Convergently, Björnberg and Nicholson (2007) point out that deficiencies in emotional cohesion create susceptibilities to destructive conflicts, putting family and business at risk. In addition, Mooney, Holahan and Amason (2007) emphasize behavioral integration (notion of team unity) as an important moderating variable between task and relationship conflicts, attenuating the relationship. Assuming, according to the employed FB definition, that members of the controlling family (at least two) have control over board seats, it's stated:

P3a: The greater the task conflict among board members, the greater the incidence of relationship conflicts in SDM.

P3b: The relationship between task and relationship conflict in FB boards will be moderated by emotional (family) cohesion. Specifically, the potential positive effect will be weakened as emotional cohesion between family members rises.

\section{Consequences of intragroup conflicts in the SDM of FB boards}

Decision-making refers to the dynamic set of actions and factors that starts by identifying a stimulus to action and ends with a specific commitment to it; i.e., the outcome of the decision-making process is the decision, whose strategic nature indicates importance in terms of resources and time horizon involved (Mintzberg, Raisinghani, \& Théorêt, 1976). Therefore, the SDM quality is linked to the quality of the strategic decision (main output), whose evaluation is a practical and theoretical problem (Nutt, 1998) at least due to three reasons: (a) multidimensional effect on performance; (b) difficult measurement; and (c) time horizon that exceeds the short term. In addition to the methodological complexity of isolating specific decisions in the midst of several factors that influence performance, the decisions impact can be reflected in the long run through multiple and even antagonistic indicators (e.g., trade-offs between risk and return on investment decisions). It's in this sense that, 
according to Mintzberg, Raisinghani and Théorêt (1976), strategic decision-making processes are complex and ambiguous, rarely providing the simplistic assurance of a right or wrong decision.

To capture the success of decisions, Nutt (1998) suggests the use of three indicators, conceptually independent of each other: adoption, time and value, indicating that decisions made in a shorter time, adopted by management and that surpass decision makers' expectations would be successful. However, the particular context of boards of directors impose some restrictions - e.g., makes little sense to talk about implementation of decisions if it's a task attributed to management. Also, in order to have some value, decisions should be adopted first incurring in the previous problem. Although time is an important variable especially in dynamic contexts, it's believed that it's not exactly preponderant for the role of director.

This study adopts the quality of decision as the main output of family firm boards related to SDM - a concept closed in nature with Amason and Sapienza (1997) understanding of qualified consensus, and particularly relevant the function of strategic counseling by board members.

\section{Quality of strategic decisions}

Decisions based on valid and coherent assumptions according to the organization's context, based on the best possible information and contemplating a wide range of perspectives relevant to the problem through a creative, logical and structured process of analysis and choices of alternatives, would be considered of good quality (Amason \& Sapienza, 1997; Olson et al., 2007). When it comes to strategic decisions in complex organizations, such requirements often outweigh individual capabilities; according to Amason (1996) both the collective board members's skills/competences and social interactions that allow them to be released are necessary to reach quality decisions.

Therefore, the board composition becomes relevant, and most researchers believe that heterogeneity - teams composed of members with different academic backgrounds and/or professional experiences - tends to develop better decisions, by the superior total stock of knowledge, and Skills (Amason, 1996; Olson et al., 2007). However, diversity alone will be sterile if not accompanied by social interactions that explore the potential of each board member in problem solving. Based on the principle that the debate produces a synthesis that is superior to any of the individually proposed solutions, authors attribute to cognitive conflict the element responsible for unlocking the potential of diversity in the decision-making process. It is through task-oriented disagreement that biases in decision making can be evidenced, generating alternatives and better selection criteria (De Wit et al., 2012; Eddleston et al., 2008; Mooney et al., 2007).

In turn, personal disagreements restrict the full development of the decision-making process (Jehn, 1994; Nosé et al., 2017). It's possible that, when engaged in relationship conflicts, members adopt a defensive posture in social interaction, retaining potential contributions and shifting the focus from the organizational task to the interpersonal conflict. Disincentives to participation would directly impact on the decision quality, limiting the creation of alternatives and careful selection of solutions. Therefore, the following propositions are elaborated:

P4a: The greater the task conflict among board members, the greater the quality of the strategic decision.

P4b: The greater the relationship conflict between board members, the lower the quality of the strategic decision.

\section{Conclusion}

Despite the apparent simplicity, the resolution of the intragroup conflict question seems far from a solution (De Dreu \& Weingart, 2003; De Wit et al., 2012), especially in the particular context of the family business. Is it possible (and under what circumstances) to obtain the benefits of conflicts minimizing associated costs? In this study a theoretical model is logically proposed to potentially and empirically demonstrate beneficial effects of 
disagreements in the SDM of family firms boards of directors. Thus, it's assumed that management is not necessarily synonymous with conflict minimization.

Specifically, it's suggested that within boards where members share a high level of competence-based trust, characterized by the presence of family members from emotionally cohesive families, relationship conflict in decision-making could be reduced. Also, the presence of independent board members (\%) might stimulate the emergence of the contradictory, thus opening the key to the quality of strategic decisions. In the other hand, restricting debate may be the most appropriate action in poorly cohesive families in boards where members are not reliable or competent enough - at the risk of generating uncontrollable misunderstandings that undermine the quality of strategic decisions.

This research is the result of deductive logic through literature review. However, it differs from similar efforts (Eddleston et al., 2008; Kellermanns \& Eddleston, 2004; Nosé et al., 2017) for developing an original integrative framework, composed of antecedents, dimensions and consequences of conflicts on the quality of strategic decisions - and not on general performance metrics, further away from the phenomenon itself. Also, it's particularly appropriate to FB boards of directors - a social context in which, although intimately related to the organizational strategy, is ignored in the literature of intragroup conflicts. It's hoped that the propositions could guide, in a logical and safe way, empirical investigations that demonstrate beneficial effects of the conflicts in the strategic decision-making process of family firm boards of directors.

\section{References}

Amason, A. C. (1996). Distinguighing the effects of functional and dysfunctional conflict on strategic decision making: Resolving the paradox for top management teams. Academy of Management Journal, 39(1), 123148. https://doi.org/10.2307/256633

Amason, A. C., \& Sapienza, H. J. (1997). The effects of top management team size and interaction norms on cognitive and affective conflict. Journal of Management, 23(4), 495-516. http://doi.org/10.1177/014920639702300401

Astrachan, J. H. (2010). Strategy in family business: Toward a multidimensional research agenda. Journal of Family Business Strategy, 1(1), 6-14. http://doi.org/10.1016/j.jfbs.2010.02.001

Astrachan, J. H., Klein, S. B., \& Smyrnios, K. X. (2002). The F-PEC scale of family influence: A proposal for solving the family business definition problem. Family Business Review, XV(1), 45-58. http://doi.org/10.1111/j.1741-6248.2002.00045.x

Bammens, Y., Voordeckers, W., \& Van Gils, A. (2011). Boards of directors in family businesses: A literature review and research agenda. International Journal of Management Reviews, 13(2), 134-152. http://doi.org/10.1111/j.1468-2370.2010.00289.x

Björnberg, Å., \& Nicholson, N. (2007). The family climate scales - Development business research. Family Business Review, XX(3), 229-246. https://doi.org/10.1111/j.1741-6248.2007.00098.x

B3. (n.d.). Segmentos de listagem. Retrieved January 15, 2019, from http://www.b3.com.br/pt_br/produtos-eservicos/solucoes-para-emissores/segmentos-de-listagem/

Corbetta, G., \& Salvato, C. (2004). Self-serving or self- actualizing? Models of man and agency costs in different types of family firms: A commentary on "Comparing the agency costs of family and non-family firms: conceptual issues and exploratory evidence". Entrepreneurship Theory \& Practice, Summer, 28(4), 355363. https://doi.org/10.1111/j.1540-6520.2004.00050.x 
Davis, J. H., Schoorman, F. D., \& Donaldson, L. (1997). Toward a stewardship theory of management. Academy of Management Review, 22(1), 20-47. https://doi.org/10.2307/259223

Davis, P. S., \& Harveston, P. D. (1999). In the founder's shadow: Conflict in the family firm. Family Business Review, 12(4), 311-323. https://doi.org/10.1111/j.1741-6248.1999.00311.x

Davis, P. S., \& Harveston, P. D. (2001). The phenomenon of substantive conflict in the family firm: A crossgenerational study. Journal of Small Business Management, 39(1), 14-30. https://doi.org/10.1111/04472778.00003

De Dreu, C. K. W., \& Weingart, L. R. (2003). Task versus relationship conflict, team performance, and team member satisfaction: A meta-analysis. Journal of Applied Psychology, 88(4), 741-749. http://doi.org/10.5465/APBPP.2002.7516590

De Dreu, C. K. W., \& Gelfand, M. J. (2008). Conflict in the workplace: Sources, functions, and dynamics across multiple levels of analysis. In C. K.W. De Dreu, \& M. J. Gelfand (Eds.), The psychology of conflict and conflict management in organizations (pp. 3-54). New York: Lawrence Erlbaum Associates.

Deutsch, M. (1969). Conflicts: Productive and destructive. Journal of Social Issues, 25(1), 7-41. http://doi.org/10.1111/j.1540-4560.1969.tb02576.x

De Wit, F. R. C., Greer, L. L., \& Jehn, K. A. (2012). The paradox of intragroup conflict: A meta-analysis. Journal of Applied Psychology, 97(2), 360-390. http://doi.org/10.1037/a0024844

De Wit, F. R. C., Jehn, K. A., \& Scheepers, D. (2013). Task conflict, information processing, and decision-making: The damaging effect of relationship conflict. Organizational Behavior and Human Decision Processes, 122(2), 177-189. http://doi.org/10.1016/j.obhdp.2013.07.002

Eddleston, K. A., \& Kellermanns, F. W. (2007). Destructive and productive family relationships: A stewardship theory perspective. Journal of Business Venturing, 22(4), 545-565. http://doi.org/10.1016/j.jbusvent.2006.06.004

Eddleston, K. A., \& Morgan, R. M. (2014). Trust, commitment and relationships in family business: Challenging conventional wisdom. Journal of Family Business Strategy, 5(3), 213-216. http://doi.org/10.1016/j.jfbs.2014.08.003

Eddleston, K. A., Otondo, R. F., \& Kellermanns, F. W. (2008). Conflict, participative decision-making, and generational ownership dispersion: A multilevel analysis. Journal of Small Business Management, 46(3), 456-484. https://doi.org/10.1111/j.1540-627x.2008.00252.x

Eisenhardt, K. M. (1989). Making fast strategic decisions in high-velocity environments. The Academy of Management Journal, 32(3), 543-576. https://doi.org/10.5465/256434

Ensley, M. D., Pearson, A. W., \& Sardeshmukh, S. R. (2007). The negative consequences of pay dispersion in family and non-family top management teams: An exploratory analysis of new venture, high-growth firms. Journal of Business Research, 60(10), 1039-1047. http://doi.org/10.1016/j.jbusres.2006.12.012

Forbes, D. P., \& Milliken, F. J. (1999). Cognition and corporate governance: Understanding boards of directors as strategic decision-making groups. Academy of Management Review, 24(3), 489-505. https://doi.org/10.2307/259138

Frank, H., Kessler, A., Nosé, L., \& Suchy, D. (2011). Conflicts in family firms: State of the art and perspectives for future research. Journal of Family Business Management, 1(2), 130-153. http://doi.org/10.1108/20436231111167219 
Instituto Brasileiro de Governança Corporativa. (2015). Código das melhores práticas de governança corporativa. São Paulo, SP: Autor.

Instituto Brasileiro de Governança Corporativa. (2018). Protocolo familiar: Aspectos da relação família e negócios. São Paulo, SP: Autor.

Jehn, K. A. (1994). Enhancing effectiveness: An investigation of advantages and disadvantages of value-based intragroup conflict. International Journal of Conflict Management, 5(3), 223-238. http://doi.org/10.1108/eb022801

Jehn, K. A., \& Mannix, E. A. (2001). The dynamic nature of conflict: A longitudinal study of intragroup conflict and group performance. Academy of Management Journal, 44(2), 238-251. https://doi.org/10.5465/3069453

Kellermanns, F. W., \& Eddleston, K. A. (2004). Feuding families: When conflict does a family firm good. Entrepreneurship Theory and Practice, 28(3), 209-228. https://doi.org/10.1111/j.1540-6520.2004.00040.x

Kellermanns, F. W., \& Eddleston, K. A. (2007). A family perspective on when conflict benefits family firm performance. Journal of Business Research, 60(10), 1048-1057. http://doi.org/10.1016/j.jbusres.2006.12.018

Kidwell, R. E., Kellermanns, F. W., \& Eddleston, K. A. (2012). Harmony, justice, confusion, and conflict in family firms: Implications for ethical climate and the "fredo effect". Journal of Business Ethics, 106(4), 503-517. http://doi.org/10.1007/s10551-011-1014-7

Leblanc, R., \& Schwartz, M. S. (2007). The black box of board process: Gaining access to a difficult subject. Corporate Governance, 15(5), 843-851. http://doi.org/10.1111/j.1467-8683.2007.00617.x

McKee, D., Madden, T. M., Kellermanns, F. W., \& Eddleston, K. A. (2014). Conflicts in family firms: The good and the bad. In L. Melin, M. Nordqvist, \& P. Sharma (Eds.), Sage handbook of family business (Chap. 26, pp. 514-528). http://doi.org/10.4135/9781446247556.n26

Memili, E., Chang, E. P. C., Kellermanns, F. W., \& Welsh, D. H. B. (2015). Role conflicts of family members in family firms. European Journal of Work and Organizational Psychology, 24(1), 143-151. http://doi.org/10.1080/1359432X.2013.839549

Mintzberg, H., Raisinghani, D., \& Théorêt, A. (1976). The structure of "unstructured" decision processes. Administrative Science Quarterly, 21(2), 246-275. https://doi.org/10.2307/2392045

Monks, R. A. G., \& Minow, N. (2004). Corporate governance. Malden, MA: Blackwell Publishing.

Mooney, A. C., Holahan, P. J., \& Amason, A. C. (2007). Don't take it personally: Exploring cognitive conflict as a mediator of affective conflict. Journal of Management Studies, 44(5), 733-758. http://doi.org/10.1111/j.1467-6486.2006.00674.x

Nordqvist, M. (2012). Understanding strategy processes in family firms: Exploring the roles of actors and arenas. International Small Business Journal, 30(1), 24-40. https://doi.org/10.1177/0266242611407413

Nosé, L., Korunka, C., Frank, H., \& Danes, S. M. (2017). Decreasing the effects of relationship conflict on family businesses: The moderating role of family climate. Journal of Family Issues, 38(1), 25-51. http://doi.org/10.1177/0192513X15573869

Nutt, P. C. (1998). Framing strategic decisions. Organization Science, 9(2), 195-216. http://doi.org/10.1007/s10869-007-9037-x

Olson, B. J., Parayitam, S., \& Bao, Y. (2007). Strategic decision making: The effects of cognitive diversity, conflict, and trust on decision outcomes. Journal of Management, 33(2), 196-222. http://doi.org/10.1177/0149206306298657 
Rousseau, M. B., Kellermanns, F., Zellweger, T., \& Beck, T. E. (2018). Relationship conflict, family name congruence, and socioemotional wealth in family firms. Family Business Review, 31(4), 397-416. http://doi.org/10.1177/0894486518790425

Sharma, P., Chrisman, J. J., \& Gersick, K. E. (2012). 25 years of family business review: Reflections on the past and perspectives for the future. Family Business Review, 25(1), 5-15. http://doi.org/10.1177/0894486512437626

Tagiuri, R., \& Davis, J. (1996). Bivalent attributes of the family firm. Family Business Review, 9(2), 199-208. http://doi.org/10.1111/j.1741-6248.1996.00199.x

Tjosvold, D. (1985). Implications of controversy research for management. Journal of Management, 11(3), 21-37. http://doi.org/10.1177/014920638501100303

\section{Authors}

Pedro Braga Sotomaior Karam

Av. Professor Luciano Gualberto, 908, 05508-010, São Paulo, SP, Brasil

E-mail address: pedrobskaram@usp.br

(D) https://orcid.org/0000-0002-3150-7512

Claudio Antonio Pinheiro Machado Filho

Av. Professor Luciano Gualberto, 908, 05508-010, São Paulo, SP, Brasil

E-mail address: capfilho10@ gmail.com

(1D) https://orcid.org/0000-0002-6733-5142

Gustavo Abib

Av. Prefeito Lothário Meissner, 632, 2º andar, 80210-170, Curitiba, PR, Brasil

E-mail address: gustavo.abib@gmail.com

(D) https://orcid.org/0000-0002-8768-9669

\section{Contributions}

1st author: Led the project that originated this publication. Mainly responsible for the definition of the research problem, the development of the literature review, the creation of propositions and conclusions.

2nd author: worked together with Pedro on the conception of the research question. Played an important role in refining the literature review, and in the development of conclusions.

3rd author: together with the first two authors, worked on the conception of the research question. He took an important role in developing the propositions, as well as reviewing all the article before submission.

\section{Funding}

The authors reported that there is no financial support for the research in this article.

\section{Conflict of Interest}

The authors have stated that there is no conflict of interest.

\section{Plagiarism Check}

The RAC maintains the practice of submitting all documents approved for publication to the plagiarism check, using specific tools, e.g.: iThenticate. 